\title{
Reeleição para a Câmara dos Deputados brasileira em 2006 e as incertezas do sistema eleitoral
}

\author{
Alvaro Augusto de Borba Barreto*
}

\begin{abstract}
Resumo
A pesquisa relaciona o sucesso ou o fracasso na tentativa de reeleição dos deputados federais no pleito de 2006 com a votação individual e o posicionamento de cada um na lista, comparados a 2002, na tentativa de verificar se a performance em alguns desses indicadores pode ser a garantia para a manutenção do mandato parlamentar. São encontradas situações correspondentes a cada uma das oito combinações possíveis, as quais, ao serem analisadas, demonstram que não há fórmula de sucesso na atual configuração do sistema eleitoral: fazer mais votos e/ou melhorar o posicionamento na lista não são suficientes para a manutenção do mandato, bem como desempenho negativo em comparação ao pleito anterior não elimina esta possibilidade.
\end{abstract}

Palavras-chave: reeleição, renovação parlamentar, sistema político, Câmara dos Deputados.

\section{Introdução}

tema da reeleição na Câmara dos Deputados brasileira é motivo de atenção de pesquisadores pelo menos desde os anos 1970. Nessas quatro décadas, foram discutidos os procedimentos metodológicos mais adequados para mensurar o fenômeno, bem como os índices registrados a partir de tais modelos. Igualmente,

* Professor do Instituto de Sociologia e Política, Pelotas, Universidade Federal de Pelotas. Endereço eletrônico: albarret.sul@terra.com.br. 


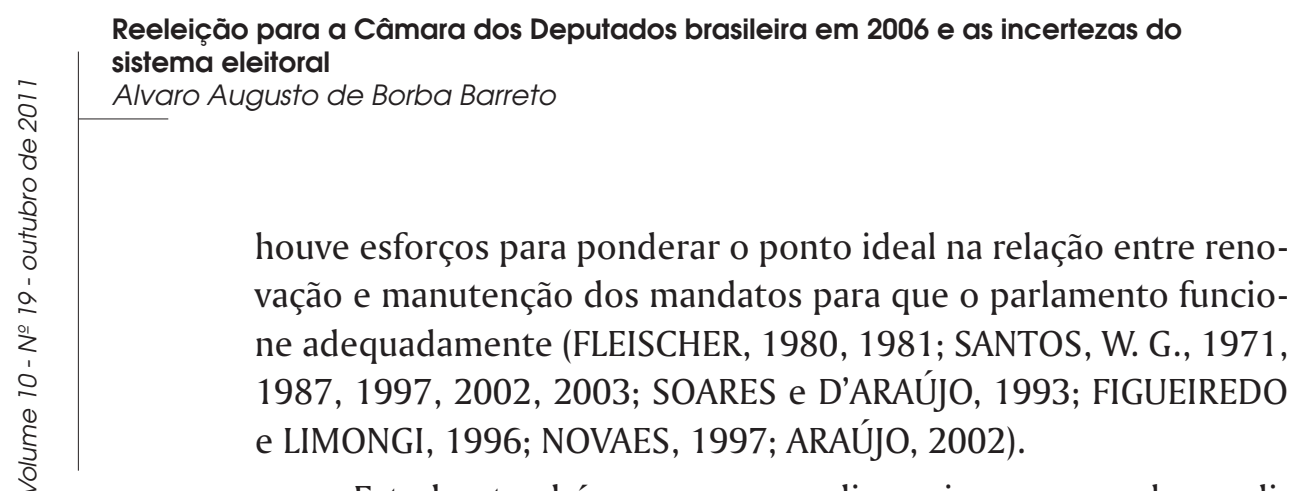

Estudos também procuraram dimensionar o papel que diferentes fatores exercem na incidência da reeleição, tais como: a campanha eleitoral (recursos gastos e exposição ao Horário Gratuito de Propaganda Eleitoral), a migração partidária, as peculiaridades da disputa (apoio ao presidente e ao governador; e, após o advento da reeleição para o executivo, o fato de o titular nacional ou estadual concorrer ou não). A discussão mais forte acabou por girar em torno da influência exercida por dois tipos de elementos: o desempenho de atividades legislativas (número de mandatos, participação em comissões e na liderança partidária; pertencimento à mesa diretora; atuação como defensor de determinada corrente da opinião pública; investimento na especialização em alguma temática) ou a atuação em benefício de suas bases eleitorais, notadamente por meio da obtenção de investimentos públicos destinadas a aqueles municípios em que o parlamentar apresenta ou busca apresentar bom desempenho eleitoral (AMES, 1995, 2003; SAMUELS, 1997, 2000, 2003; MARENCO DOS SANTOS, 1997, 2000, 2006; FIGUEIREDO \& LIMONGI, 1999, 2002; SCHMITT, 1999; PEREIRA \& RENNÓ, 2001, 2007; CARNEIRO \& SCHMITT, 2001).

Outra linha de investigação procura enfatizar o modo como as regras que fundam o sistema eleitoral influenciam a dinâmica da competição política e, consequentemente, os resultados obtidos nas tentativas de reeleição. A bibliografia tem apontado que o sistema eleitoral brasileiro segue lógicas divergentes, alternadamente com traços favoráveis aos grandes e aos pequenos partidos, mas também contrários a ambos e favoráveis aos candidatos. Assim, os distritos apresentam elevada magnitude, o que amplia as possibilidades de obtenção de espaço político formal para as 
pequenas legendas. Porém, há variação significativa entre eles (8 a 70, no caso da Câmara dos Deputados), o que, somado à fórmula eleitoral adotada no país, e ao número de listas em disputa e ao contingente eleitoral de cada distrito, produz competições de intensidades bastante distintas. Por seu turno, a cláusula de exclusão corresponde ao cociente eleitoral, sendo que este é estabelecido pela cota Hare, considerada aquela mais exigente e que, por isso, mais beneficia as grandes legendas. A cota Hare, por dividir o número de cadeiras pela magnitude, tende a gerar mais vagas não ocupadas no primeiro procedimento (as chamadas sobras), as quais, por sua vez, são distribuídas pela modalidade sistema de maiores médias, mas apenas aos partidos que atingem o cociente eleitoral, o que é considerada outra medida que beneficia as grandes legendas. Contudo, novamente a ajudar as pequenas legendas, há a possibilidade de coligação entre os partidos, que formam uma lista única para fins de distribuição de cadeiras, sem que ocorra, neste cálculo, qualquer ponderação entre a quantidade de votos que cada parceiro agrega ao conjunto. As " $x$ " cadeiras obtidas pela lista (seja ela formada por um partido ou por vários) são distribuídas, simplesmente, aos " $x$ " nomes mais votados daquela lista.

Nesse ponto, podem se somar mais características divergentes em relação aos princípios seguidos pelas demais do sistema eleitoral brasileiro: as regras autorizam os partidos/coligações a lançarem mais candidatos do que cadeiras em disputa, mas estes não têm como hierarquizar a preferência entre tais candidatos, pois a lista é aberta, ou seja, não ordenada previamente. Logo, o posicionamento final dos concorrentes (e a maior ou menor probabilidade de ser eleito) vai depender das preferências que cada um conquistar, pois o eleitor tem a possibilidade de escolher apenas um nome. Essas peculiaridades estimulam campanhas individualizadas, podem acirrar a disputa intrapartidária e diminuem drasticamente as possibilidades de influência dos partidos sobre a definição dos eleitos. No entanto, o eleitor ainda pode preterir 


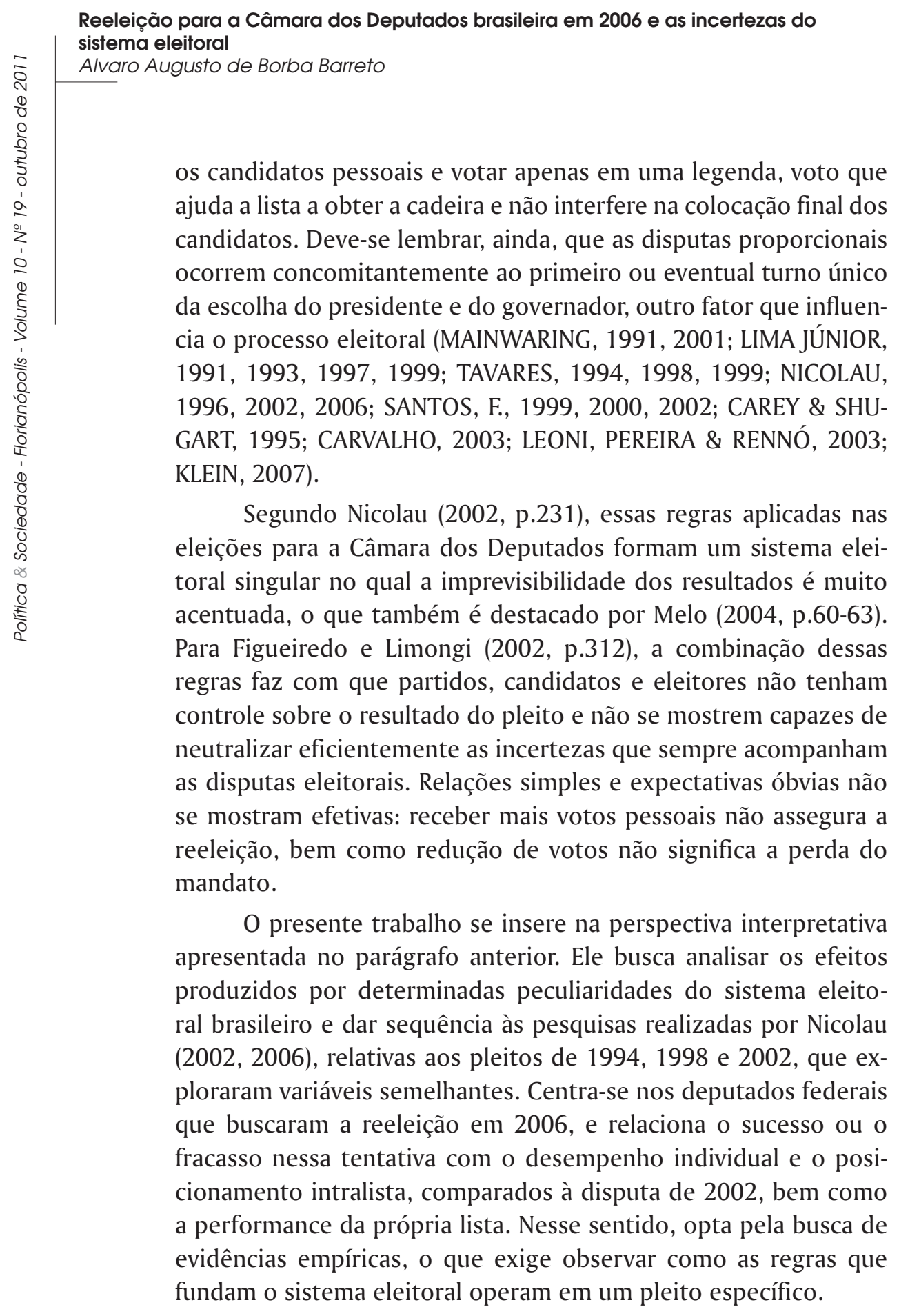


O trabalho está estruturado em quatro seções. A primeira é de ordem metodológica: apresenta o modo como os dados foram obtidos e ordenados, indicando as principais decisões que subsidiam a pesquisa. A seção dois traz os resultados referentes às taxas de reapresentação e de reeleição dos deputados federais, e procura compará-las a outras séries históricas. A terceira parte agrega informações sobre a performance pessoal e o posicionamento do parlamentar na lista, no intuito de testar a imprevisibilidade do sistema eleitoral brasileiro. A seção quatro insere um novo elemento: a performance comparada das listas pelas quais os candidatos concorreram.

\section{Aspectos metodológicos}

Do ponto de vista abstrato, não há dificuldade para a definição das categorias de análise: "reapresentação" indica os parlamentares que buscam subsequientemente um novo mandato para o mesmo cargo, sendo mensurada como o produto da divisão do número de candidatos à reeleição pelo total de vagas existentes na legislatura que se encerra. Se houve sucesso na tentativa, tem-se a "reeleição", ou seja, o "grau de recondução, numa nova legislatura, de parlamentares provenientes da(s) anterior(es)" (SCHMITT, 1999, p.128). Como no período não houve mudança no número de cadeiras em disputa, o que poderia afetar a probabilidade de um parlamentar manter a vaga, o cálculo também é simples: a "taxa de reeleição" é fruto da divisão do número de sucessos pelo número total de reapresentações (FIGUEIREDO e LIMONGI, 1996), sendo correspondente ao que Santos $(1997,2002)$ chama de "conservação" e Fleischer (1980) de "taxa de retorno ou permanência".

Aqueles que não conseguem a reeleição, também chamados de "derrotados", contribuem para a "renovação parlamentar", ou seja, a "mudança na composição dos membros de um parlamento entre duas legislaturas" (ARAÚJO, 2002, p.11). De modo mais preciso, eles compõem a "renovação líquida ou deliberada", concebida como 


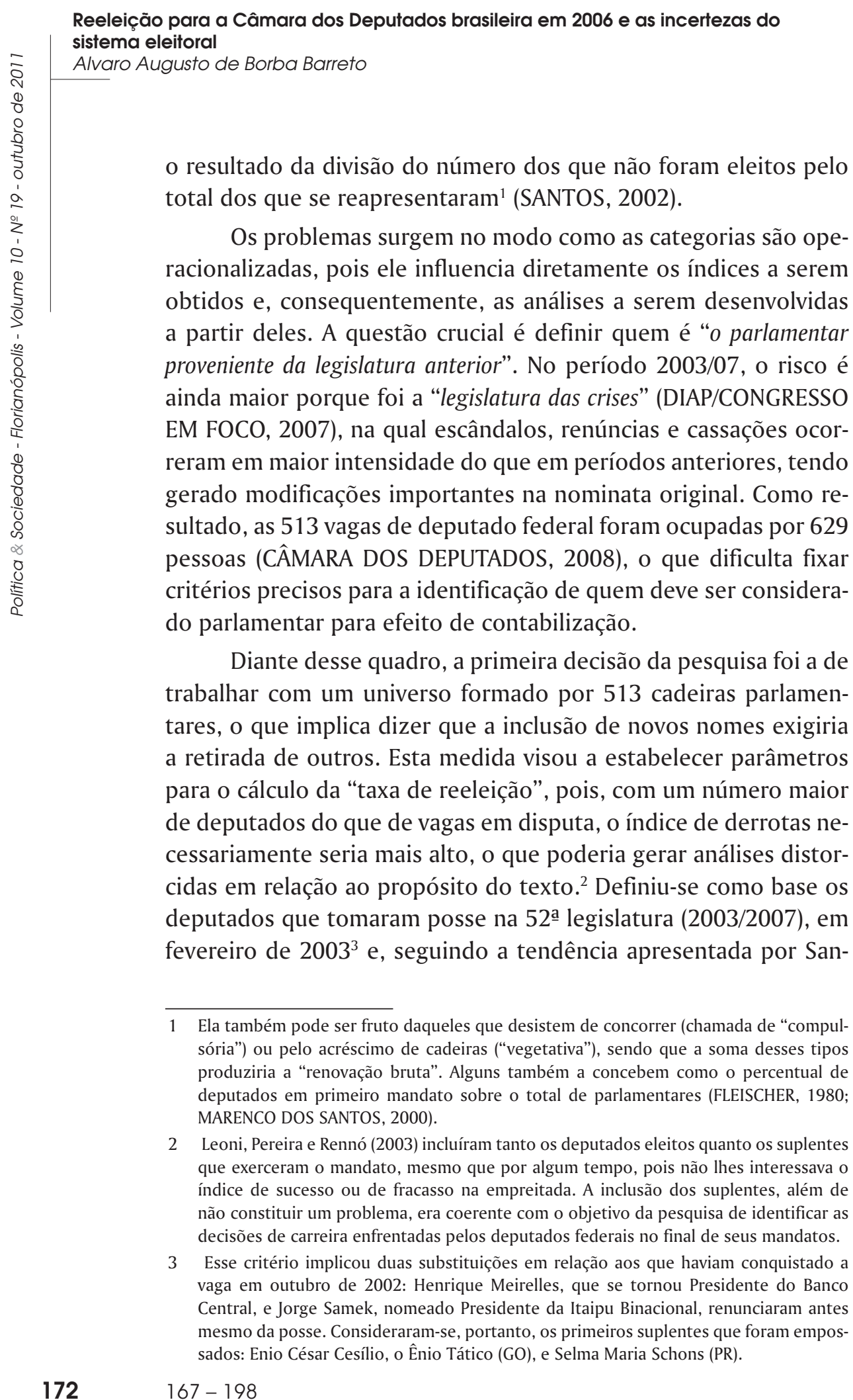


tos (1971), Fleischer (1980, 1981), Schmitt (1999) e Araújo (2002), não foram incluídos suplentes que tenham assumido o mandato ao longo de quatro anos, independentemente da condição (temporária ou definitivamente).

Desse universo, seriam acompanhados todos aqueles que buscaram permanecer no cargo em 2006, tendo concorrido pelo mesmo distrito de quatro anos antes. Identificaram-se 393 parlamentares nessa situação, equivalentes a $76,6 \%$ do total (Tabela 1). Foram excluídos: três que concorreram à reeleição, porém em distrito diferente ${ }^{4} ; 45$ que pleitearam outros cargos ${ }^{5}$; e 72 que "não concorreram". Nesta categoria figuram situações distintas: três licenciaram-se porque foram nomeados para cargo político-administrativo e não retornaram à Câmara ${ }^{6}$; um renunciou por ter sido nomeado para o Tribunal de Contas da União ${ }^{7} ; 16$ elegeram-se prefeito em $2004^{8}$; quatro foram cassados pelo legislativo ${ }^{9}$; oito faleceram..$^{10}$ Os demais (40) decidiram se "aposentar" ou não concorrer a nenhum cargo eletivo naquele momento, sendo que grande parte tomou a decisão depois de ter sido envolvido em um ou

4 Apenas um obteve sucesso (José Fuscaldi Cesílio): ele havia sido eleito pelo Distrito Federal e foi reeleito por Goiás. Os outros dois concorreram pelo Rio de Janeiro, quando haviam sido eleitos pelo Pará (Babá) e por São Paulo (Vanderlei Assis de Souza).

511 concorreram a governador, cinco a vice, 15 a senador e cinco a primeiro ou segundo suplente. Nove preferiam concorrer a deputado estadual.

6 Patrus Ananias (MG) e Paulo Bernardo (PR), ambos nomeados ministros, e Aloysio Nunes Ferreira (SP), nomeado Secretário estadual.

7 Augusto Nardes (RS).

8 Tecnicamente, quem é eleito para um cargo dessa natureza tem de renunciar ao mandato. O mesmo ocorreu com os parlamentares que tomaram posse como governador ou vice, em 1ํ de janeiro de 2007, pois, como a legislatura prosseguia até fevereiro daquele ano e os dois cargos não são legalmente acumuláveis, eles tiveram de renunciar e foram substituídos por suplentes que se tornaram, assim, deputados efetivos.

9 José Dirceu (SP), Pedro Corrêa (PE), Roberto Jefferson (RJ) e André Luiz (RJ).

10 Adauto Pereira de Lima (PB), Miguel Arraes (PE), Ricardo Fiúza (PE), Afonso Gil Castelo Branco (PI), Francisca das Chagas Trindade (PI), José Carlos Martinez (PR), Sérgio de Carvalho (RO) e Moises Lipnik (RR). 


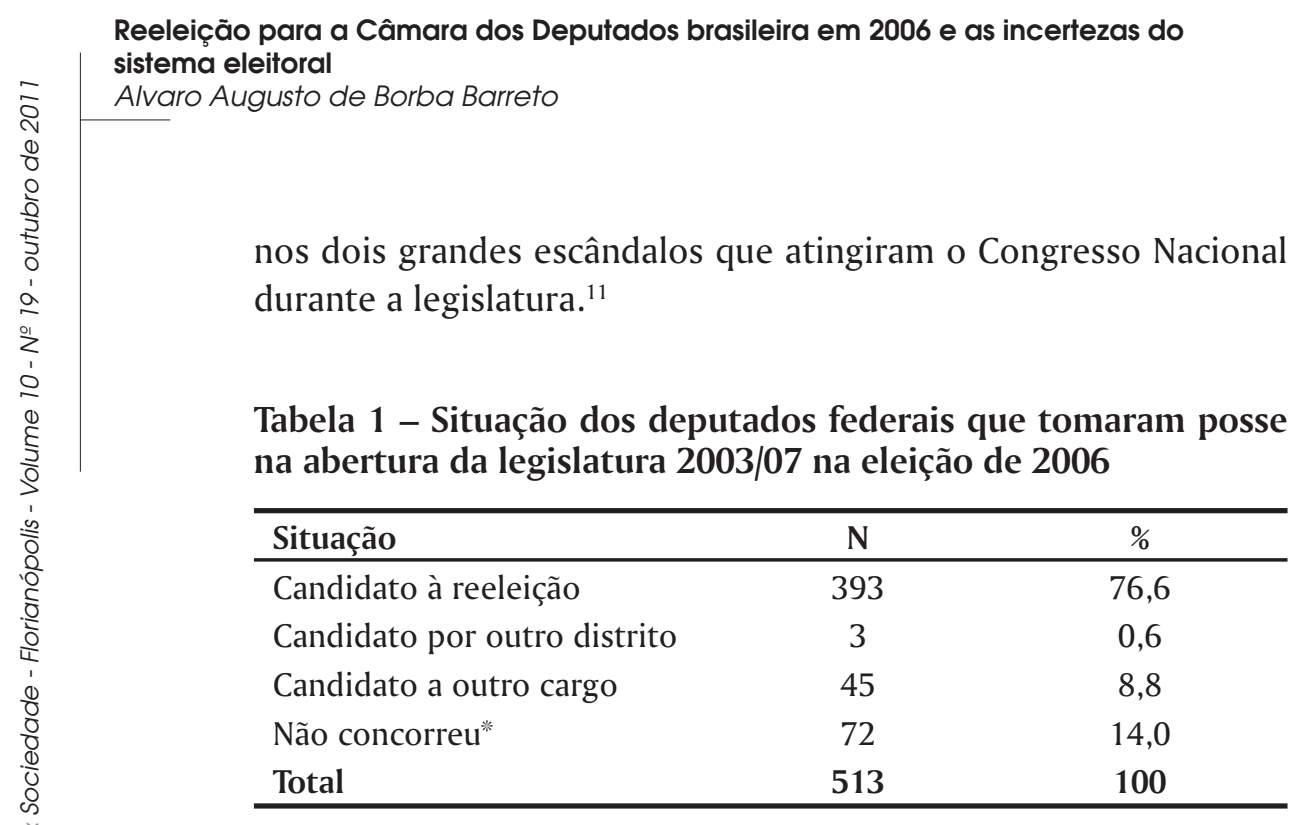

Fonte: Câmara dos Deputados, 2008; TSE, Resultados - Eleição 2006; DIAP/Congresso em Foco, 2007.

* desistência (40), eleito prefeito (16), nomeado TCU (1), falecido (8), cassado em plenário (4), licenciado (3).

Os 393 deputados foram classificados conforme três critérios: o resultado da tentativa de reeleição; a votação e o posicionamento na lista que foram obtidos em 2006, quando comparados a 2002. Posteriormente, foram incluídos dados relativos ao número de cadeiras conquistadas pelas listas pela quais cada um concorreu nas duas eleições.

A votação está expressa pela participação percentual no total de votos válidos de cada pleito, seguindo critério estabelecido por Nicolau (2002). Evitou-se considerar o número absoluto, pois o tamanho do eleitorado e o total de votos válidos tendem a au-

11 Dentre os envolvidos no "mensalão" ou na "máfia das ambulâncias", houve duas situações básicas, sem contar os casos de cassação, referenciados anteriormente: (a) conclusão do mandato e (b) renúncia como forma de evitar a perda dos direitos políticos (seis casos). Esta se subdivide em três possibilidades: (a) tentativa de reeleição; (b) candidatura a outro cargo eletivo e (c) desistência. Seguindo a decisão metodológica que a subsidia, a pesquisa considerou todos aqueles que concorreram à reeleição, tenham ou não renunciado. Lembra-se, ainda, que há situações como a de José Janene (PR), uma das principais figuras do "mensalão", que escapou da cassação e pretendia concorrer, mas teve a candidatura indeferida, graças à intervenção do partido e da Justiça Eleitoral. Enfim, a categoria pode envolver tanto a decisão voluntária do parlamentar, quanto a impossibilidade legal ou partidária para o fato. 
mentar entre uma eleição e outra. Em 2006, o eleitorado brasileiro cresceu $9,2 \%$ em relação a 2002, tendo o maior índice no distrito do Amapá (22\%) e o menor no Rio Grande do Sul (5,4\%). Já os válidos foram ampliados em 7,2\%, com destaque aos estados Amazonas $(21,2 \%)$ e ao Rio de Janeiro (que apresentou variação negativa de $0,01 \%$ ). Ao definir a participação percentual, consegue-se equiparar os dois pleitos e neutralizar tal variação, mas a decisão não é neutra, pois torna possível que candidatos que tivessem obtido maior número absoluto de sufrágios em 2006, ainda assim apresentassem performance negativa - e tal situação está condicionada ao panorama de cada estado. ${ }^{12}$

Embora tecnicamente seja possível a existência de três situações: aumento, diminuição ou manutenção da participação percentual, não foi encontrado nenhum parlamentar que tenha obtido exatamente o mesmo resultado. ${ }^{13}$ Assim, ou eles apresentaram desempenho positivo ou negativo (sendo que, neste caso, como indicado acima, isso necessariamente não significa que tenha somado menos votos).

No que tange à lista pela qual concorreram, consideraram-se tanto os partidos que disputaram isoladamente ou em coligação e, nesse caso, era determinante saber quais legendas compunham a aliança. Embora 287 dos 393 parlamentares considerados (73\%) tenham disputado os dois pleitos pelo mesmo partido, contra 106 que trocaram de legenda, apenas $22(5,6 \%)$ concorreram pela mesma lista. Isso porque, entre uma eleição e outra, os partidos ingressaram em coligação ou passaram à condição de avulso, assim como, quando concorreram nas duas oportunidades em aliança, mudaram de parceiro(s) ou incluíram novas legendas. Os 22 parlamentares que concorreram pela mesma lista pertencem a um daqueles que não coligaram nos dois pleitos, pois nenhuma aliança

12 Houve 31 casos $(7,9 \%)$, sendo que cinco parlamentares melhoraram a performance em mais de $10 \%$, calculada a partir da variação no número absoluto de votos. Esses concorreram pelos estados que apresentaram o mais alto percentual de crescimento do número absoluto de votos válidos, acima de 19\% (Amapá, Amazonas, Acre e Alagoas).

13 O índice mais próximo foi $+0,006$, em dois casos. 


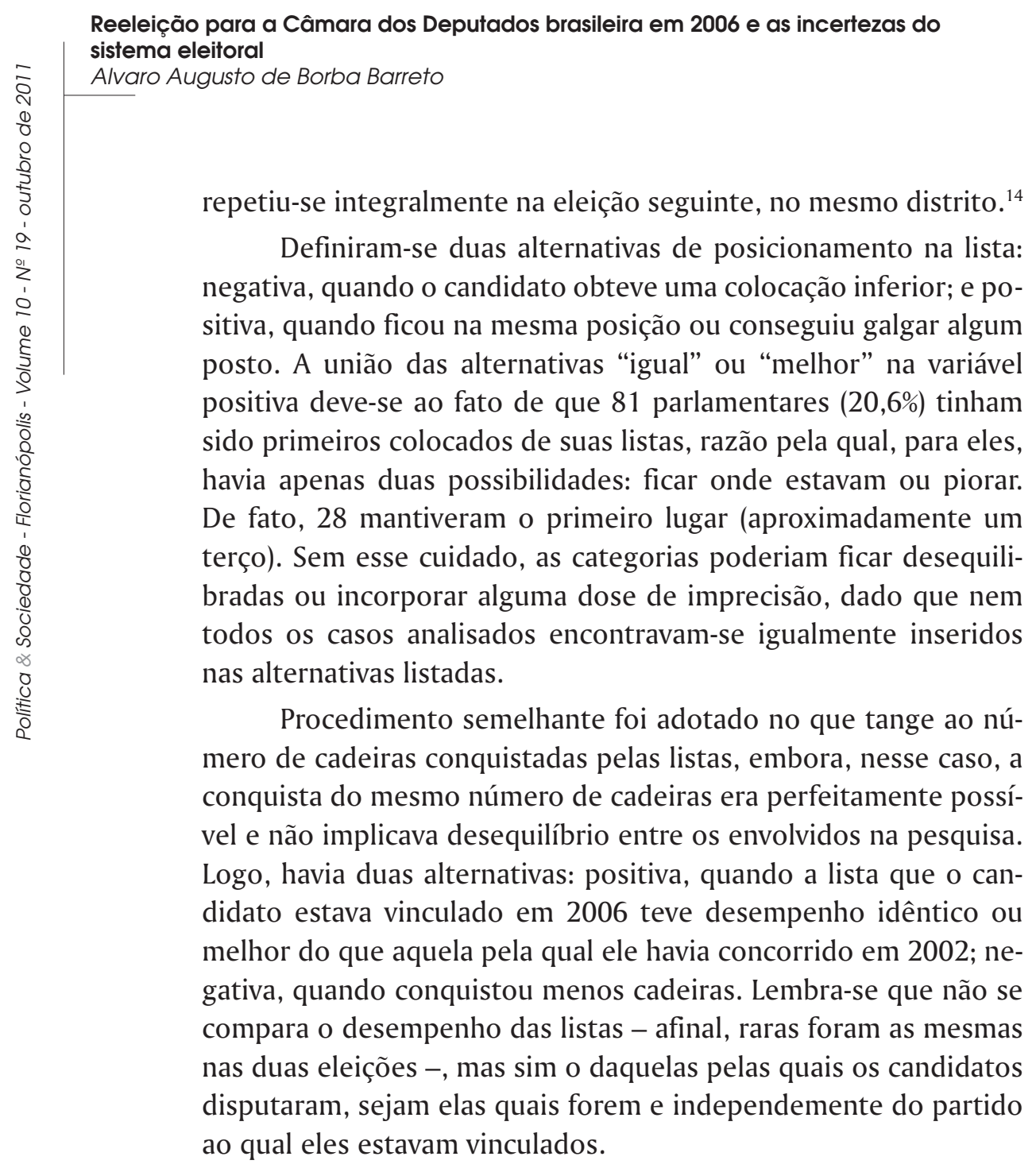

\section{Resultados}

\subsection{Reapresentação}

O primeiro dado a ser comentado é que $76,6 \%$ dos 513 parlamentares que tomaram posse em 2003 buscaram a reeleição em $2006^{15}$ - Santos (2008) traz dados muito semelhantes a estes: ha-

\footnotetext{
14 São seis partidos e seis estados: PSDB (BA e MA), PMDB (PA, PR e SP), PP (RS), Prona (SP), PSB (RS e SP) e PV (SP).

15 A taxa pode chegar a $78,9 \%$, se forem considerados aqueles que não tiveram como
} 
veria 392 candidatos à reeleição $(76,4 \%)$, um a menos do que o levantamento realizado pelo trabalho. $\mathrm{O}$ índice é superior à média de $68 \%$ relativa a 1950-2002 (SANTOS, W. G. apud PEREIRA \& RENNÓ, 2007), sendo que, nessa série histórica, apenas a eleição de 1978 registra valor mais alto (77\%) e, ainda assim, por estreita margem. $\mathrm{O}$ mesmo cenário se repete em relação às séries trazidas por: FIGUEIREDO \& LIMONGI (1996), referente a 1986-1994, cuja média é de 66,5\%; ARAÚJO (2002), para o período 1986-1998, e NICOLAU (2002) para 1998.

"Taxas de reapresentação" mais elevadas são apresentadas somente pelo DIAP/CONGRESSO EM FOCO (2007): 74,3\% em 1990, tendo passado a 78,92\% em 1994, 86,35\% em 1998, 81,09\% em 2002 e, finalmente, $87,33 \%$ em 2006. Muito provavelmente isso se deve ao fato de, ao contrário das demais, tal fonte admitir a substituição de titulares por suplentes. Apesar das diferenças, os dados confirmam que o índice mais elevado do período ocorreu no pleito mais recente em análise. Dez anos antes, frente a taxas significativamente mais discretas do que as registradas em 2006, Figueiredo e Limongi (1996) concluíram que o mandato parlamentar não parecia ser assim tão atrativo, pois se insere no âmbito de uma carreira política mais ampla, tornando-se um ponto de passagem secundário, em uma escala de valor na qual se destacam postos no executivo.

Santos $(2000,2002)$ propõe que a relevância decisória do legislativo afeta a capacidade que ele tem de reter membros. Logo, no período 1946-64, aqueles deputados que permaneciam mais tempo na casa eram políticos experientes e com passagem por cargos do executivo; atualmente, quando o poder de agenda está concentrado no Executivo, os parlamentares dotados de expertise política são também aqueles que mais rapidamente deixam o legislativo, procurando espaços alternativos de exercício do poder.

De modo semelhante, Samuels $(2000,2003)$ alega que esses índices devem-se ao fato de os membros mais proeminentes

tomar essa decisão, caso dos falecidos e dos que perderam os direitos políticos. 


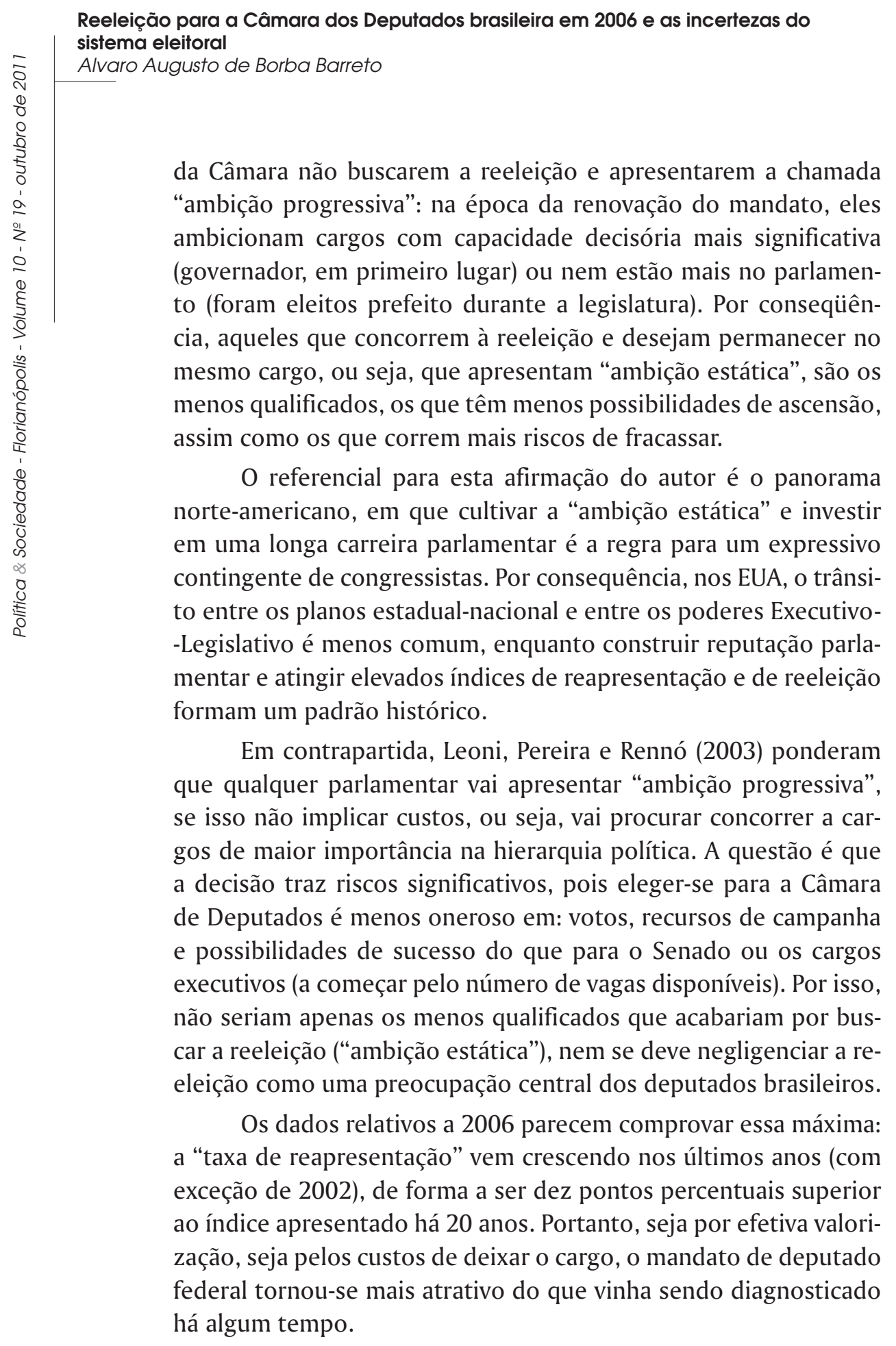




\subsection{Reeleição}

No que tange ao resultado, os dados indicam que $65,9 \%$ dos parlamentares tiveram sucesso em 2006 (Tabela 2). ${ }^{16} \mathrm{~A}$ taxa se revela inferior à média do período 1950-2002, que é de $67 \%$ (SANTOS, W. G. apud PEREIRA \& RENNÓ, 2007), e corrobora a afirmação de que os índices nacionais têm sido discretos (FLEISCHER, 1980, 1981; SANTOS, W. G., 1971, 1987, 1997, 2002, 2003; FIGUEIREDO \& LIMONGI, 1996, 2002; SCHMITT, 1999; SAMUELS, 2000, 2003; PEREIRA \& RENNÓ, 2001; NICOLAU, 2002; ARAÚJO, 2002; MORGENSTERN, 2002; LEONI, PEREIRA \& RENNÓ, 2003; RODRIGUES, 2006; DIAP/CONGRESSO EM FOCO, 2007).

Tabela 2 - Resultado obtido pelos candidatos à reeleição na Câmara dos Deputados em 2006

\begin{tabular}{lcc}
\hline Resultado & N & $\%$ \\
\hline Reeleito & 259 & 65,9 \\
Não reeleito & 134 & 34,1 \\
Total & 393 & $\mathbf{1 0 0}$ \\
\hline
\end{tabular}

Fonte: TSE, Resultados - Eleição 2006.

Quando as informações são desagregadas, verifica-se que o índice de reeleição em 2006 é sempre superior ao do período 1986-1994, que gira em torno de 51\%-63\%. (FIGUEIREDO \& LIMONGI, 1996; ARAÚJO, 2002; SANTOS, W.G. apud PEREIRA \& RENNÓ, 2007; DIAP/CONGRESSO EM FOCO, 2007) No entanto, ele é inferior aos 68-69\% do período 1998-2002. (NICOLAU, 2002, 2006; ARAÚJO, 2002; NICOLAU, 2002; SANTOS, W.G. apud PEREIRA \& RENNÓ, 2007) Enfim, o resultado foi inferior ao de 1998-2002 e ficou em um patamar superior ao que vinha sendo registrado no período 1986-1994. Isso é confirmado pelos dados do DIAP/CONGRESSO

16 O índice apresentado por Santos, W.G. (2008) é muito semelhante: $66,1 \%$, correspondente ao mesmo número de tentativas bem sucedidas (259). A diferença deve-se ao total de reapresentações consideradas (uma a menos em comparação). Isso significa que foi encontrado um fracasso a mais (134 a 133). 


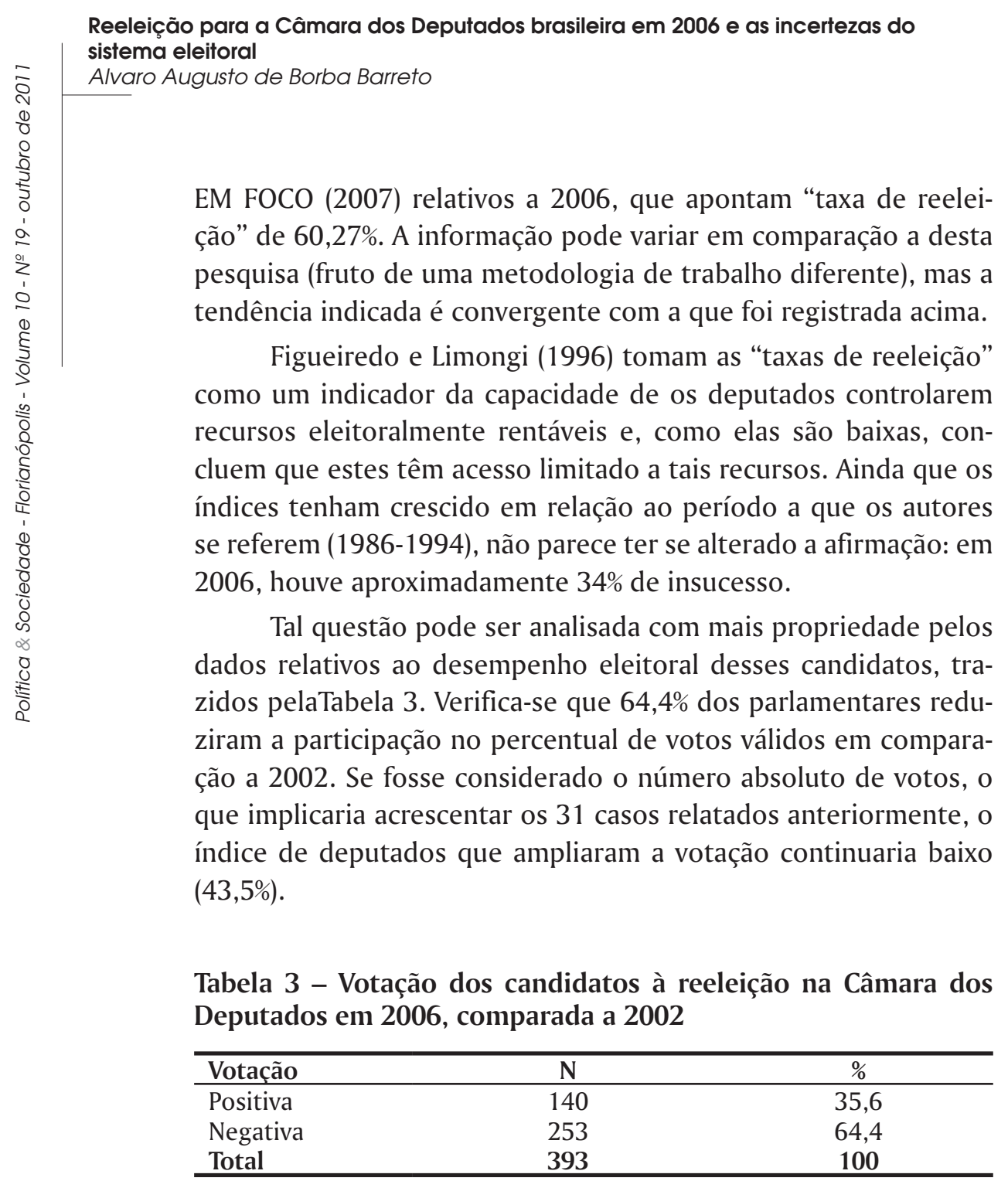

Fonte: TSE, Resultados - Eleições 2002 e 2006.

Os dados são convergentes com aqueles apresentados por Nicolau (2002), segundo os quais, em 1998, 59,2\% dos candidatos à reeleição tiveram uma performance negativa; assim como com os trazidos por Figueiredo e Limongi (2002): na eleição de 1994, 40\% daqueles que buscavam a reeleição haviam recebido mais votos em 1990. 
Informações como essas fazem com que Figueiredo e Limongi (2002) questionem as interpretações que derivam da lista aberta com representação proporcional os incentivos para que políticos cultivem o voto pessoal e adotem práticas de pork barrel. ${ }^{17}$ Os autores ponderam que os retornos eleitorais desta estratégia não são tão expressivos e tampouco inequívocos, caso contrário, a "taxa de reeleição" e a votação dos parlamentares deveriam ser muito mais significativas. Igualmente, lembram que a diversidade de padrões espaciais encontrados por Ames (2003) sugerem que a legislação eleitoral brasileira permite que os políticos lancem mãos de estratégias variadas para se eleger e reeleger. Em reforço, Nicolau (2006, p.711) argumenta que os candidatos desenvolvem estratégias de campanha diversificadas, na quais enfatizar virtudes pessoais é apenas uma, ao lado de "ressaltar algum tipo de identidade com o eleitor (territorial, profissional, de gênero, religiosa), apresentar uma campanha orientada para políticas (em defesas de temas e grupos sociais específicos). As campanhas poderiam até mesmo mobilizar a reputação partidária (....)."

Os dados também servem como indício da competitividade que se estabelece na disputa para o cargo de deputado federal, e de como é difícil a situação do detentor de mandato ao buscar a reeleição, pois novos concorrentes conseguem erodir os votos anteriormente conquistados. Identificar quem são esses "novos concorrentes" exige um tipo de análise que o texto não se propõe a fazer, mas a bibliografia traz indícios. Nicolau $(2002,2006)$ sugere que a grande maioria dos eleitores faz suas escolhas, não só às vésperas do pleito, como a partir de estímulos gerados durante a própria campanha eleitoral, os quais não estão associados a um julgamento do mandato, já que um número reduzido de eleitores tem condições de fazer uma avaliação retrospectiva dessa atuação. Neste cenário, ao qual se somam a falta de informação e de interesse pelo pleito, e a percepção negativa sobre a política em geral, abre-se espaço a políticos que não são deputados federais

17 Para uma análise dessa mesma temática, ver MARENCO DOS SANTOS (2006). 


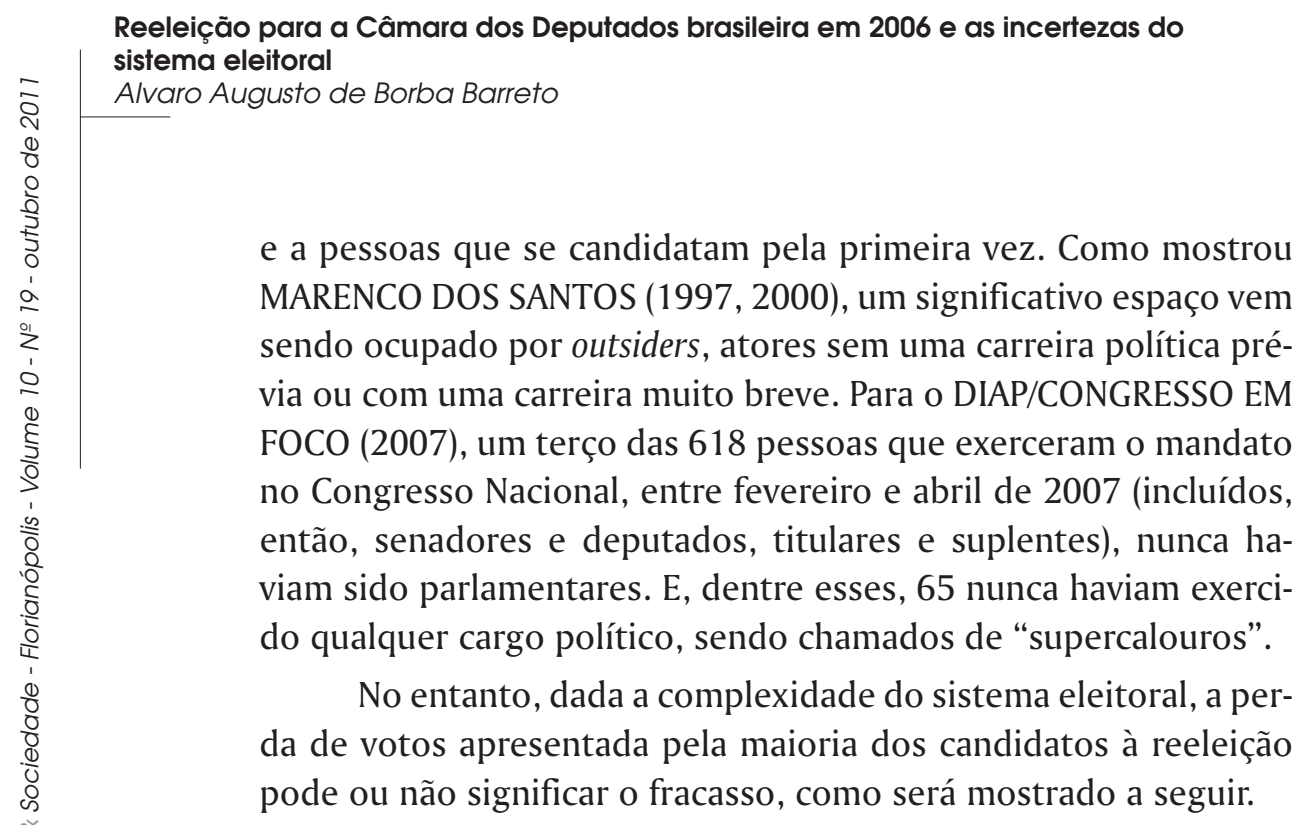

\section{Outros elementos relacionados à tentativa de reeleição}

Se for considerado "normal" que um candidato que aumentou a votação consiga a reeleição e que aquele que a reduziu não obtenha sucesso, a maioria dos casos trazidos pela Tabela $4 \mathrm{cum}$ prem esta expectativa ( 250 ou $63,6 \%)$. O índice é um pouco menor do que os $66,7 \%$ observados por Nicolau (2002, p.230-231) nas eleições para a Câmara dos Deputados de 1998. Naquele pleito, cerca de $39 \%$ dos candidatos somaram mais votos e se reelegeram, contra $32,6 \%$ em 2006 . Outros $28 \%$ somaram menos votos e não se reelegeram na disputa nacional, sendo que, no pleito atual, o índice foi maior (31\%). Por sua vez, os 3,1\% (12 em 393) que perderam o mandato, embora tenham aumentado a votação, é um valor bem menor do que os 15\% identificados por Figueiredo e Limongi (2002) para os pleitos de 1990 a 1998 na Câmara Federal. Na mesma medida, o daqueles que tiveram sucesso, quando perderam votos, um terço (131 em 393), mostra-se inferior aos aproximadamente 40\% que estão na mesma situação, em 1994 e em 1998. 
Tabela 4 - Resultado atingido pelos candidatos à reeleição na Câmara dos Deputados em 2006 e votação obtida em relação a 2002

\begin{tabular}{lccc}
\hline Votação & Reeleito & Não reeleito & Total \\
\hline Positiva & $128(32,6 \%)$ & $12(3,1 \%)$ & $140(35,6 \%)$ \\
Negativa & $131(33,3 \%)$ & $122(31,0 \%)$ & $253(64,4 \%)$ \\
Total & $\mathbf{2 5 9 ( 6 5 , 9 \% )}$ & $\mathbf{1 3 4 ( 3 4 , 1 \% )}$ & $393(\mathbf{1 0 0 \% )}$ \\
\hline
\end{tabular}

Fonte: TSE, Resultados - Eleições 2002 e 2006.

Ao cruzarem-se os dados relativos à votação individual com a tentativa de reeleição, chega-se a resultados aparentemente paradoxais. Dos 140 deputados que aumentaram a participação relativa no total de votos nominais, a grande maioria se reelegeu (128 ou $91,4 \%)$, mas 12 fracassaram $(8,6 \%)$. Por outro lado, dos 253 que diminuíram a votação, pouco mais da metade teve sucesso (131 ou $51,8 \%$ ), o que faz com que a maioria dos deputados tenha se reelegido, apesar de ter diminuído a performance (131 em 259 ou $50,6 \%$ ).

Este cenário traz a mesma tendência identificada pela análise de Nicolau (2002), relativa a 1998, mas há diferenças nos índices, as quais mostram que, em 2006, as "anormalidades" se ampliaram: mais deputados tiveram desempenho negativo $(64,4 \%$ contra $59,2 \%$ ) e mais não se elegeram, apesar de terem apresentado desempenho melhor (8,6\% contra 5,1\%). Em contraste, um índice menos intenso de candidatos com menos votos conseguiu se reeleger $(51,8 \%$ contra $52,9 \%)$.

Enfim, há uma quantidade significativa de situações "anormais" (cerca de 36\%), logo a performance individual não se mostra suficiente para explicar o sucesso ou o fracasso na tentativa da reeleição. Torna-se necessário agregar novos elementos à análise para compreender esses fatos, caso da colocação do candidato na lista partidária, visto que, a rigor, este é um quesito mais decisivo na disputa.

Em termos de posicionamento na lista, há praticamente a igualdade (Tabela 5): 198 candidatos colocaram-se mais atrás na 


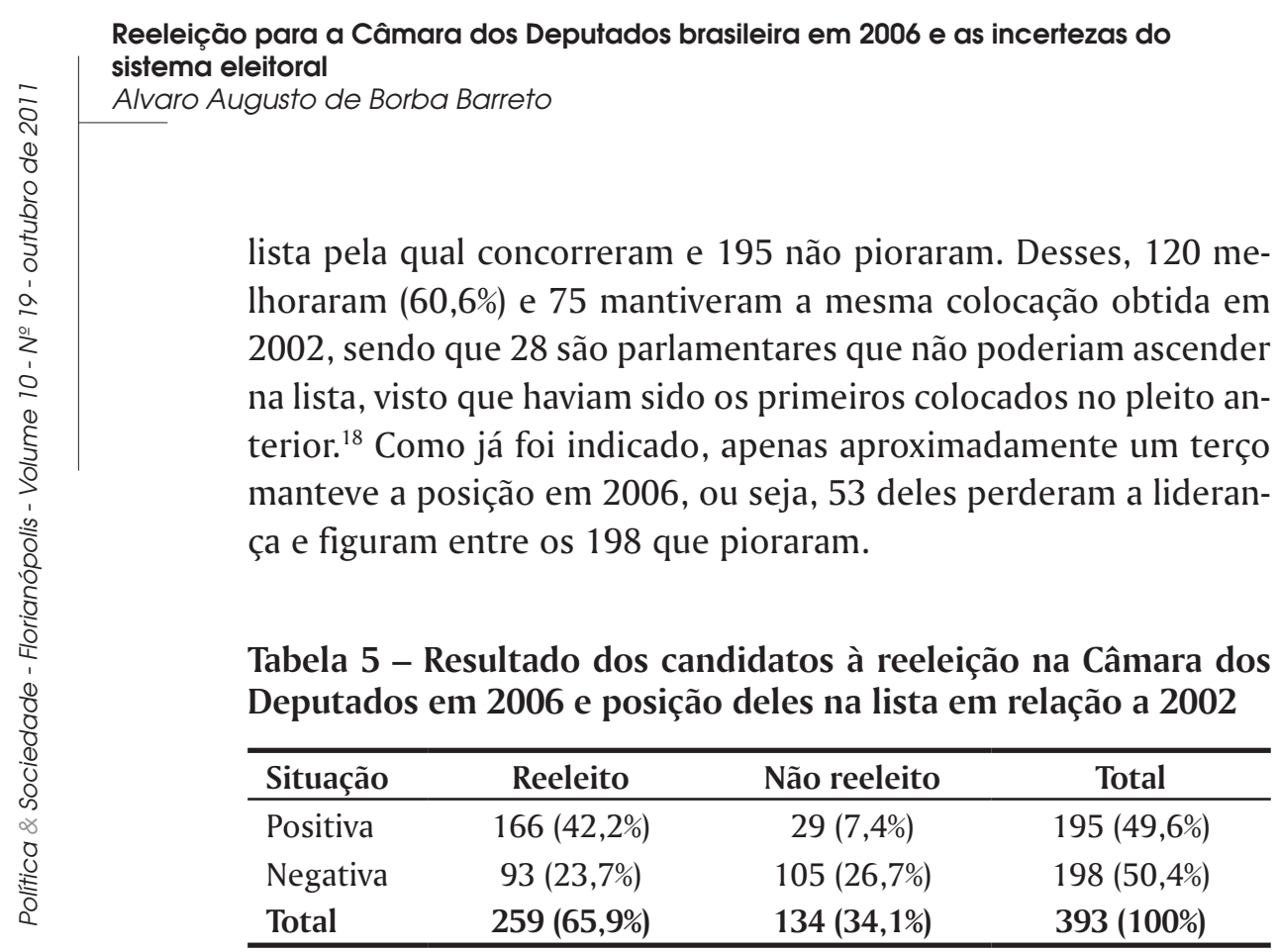

Fonte: TSE, Resultados - Eleições 2002 e 2006.

Quando se analisa a relação entre posicionamento na lista e resultado na tentativa de reeleição, o cenário torna-se um pouco menos inusitado do que aquele relativo à performance individual, pois 271 ou $68,9 \%$ dos candidatos estão dentro das expectativas: caíram de posição e não se reelegeram (105), mantiveram ou melhoraram e se reelegeram (166); a maioria dos que pioraram, fracassou $(53,6 \%)$, bem como a maioria dos que não pioraram, conseguiu um novo mandato $(85,1 \%)$. A questão é que 29 não pioraram e, ainda assim, não se reelegeram e 93 colocaram-se mais atrás na lista e, nem por isso, deixaram de conquistar a vaga.

Essas informações mostram que, quando se trata de reeleição, performance individual e colocação na lista são variáveis relacionadas, porém distintas, e a melhoria em uma não torna automática, nem necessária a ocorrência do avanço na outra. O máximo que se pode afirmar é haver a tendência de que isso se verifique, mas a confirmação depende do estudo dos casos específicos.

18 Logo, 70,6\% que poderiam melhorar (120 de 170), fizeram-no. 
Na sequência (Tabela 6), organizaram-se as 393 tentativas de reeleição, a partir das três variáveis observadas até o momento. São oito as possíveis combinações, haja vista que cada uma contempla duas possibilidades: colocação individual na lista pior ou não pior; performance do candidato melhor ou pior, busca da reeleição bem sucedida ou fracassada.

Tabela 6 - Comparação entre resultado dos candidatos à reeleição na Câmara dos Deputados em 2006, votação individual e posicionamento na lista, em relação a 2002

\begin{tabular}{lccccc}
\hline Posição & \multicolumn{2}{c}{ Reeleito } & \multicolumn{2}{c}{ Não reeleito } & \multirow{2}{*}{ Total } \\
na Lista & + Votos & - Votos & + Votos & - Votos & \\
\hline Positiva & $105(26,7 \%)$ & $61(15,5 \%)$ & $3(0,8 \%)$ & $26(6,6 \%)$ & $195(49,6 \%)$ \\
Negativa & $23(5,9 \%)$ & $70(17,8 \%)$ & $9(2,3 \%)$ & $96(24,4 \%)$ & $198(50,4 \%)$ \\
Sub-total & $128(32,6 \%)$ & $131(33,3 \%)$ & $12(3,1 \%)$ & $122(31,0 \%)$ & \\
Total & \multicolumn{2}{c}{$\mathbf{2 5 9 ( 6 5 , 9 \% )}$} & \multicolumn{1}{c}{$134(34,1 \%)$} & $393(100 \%)$ \\
\hline
\end{tabular}

Fonte: TSE, Resultados - Eleições 2002 e 2006.

As relações entre as variáveis mostram a diversidade de situações: foram encontrados exemplos nas oito combinações possíveis. Duas correspondem aos resultados esperados, em uma primeira análise. De um lado, 105 candidatos foram reeleitos porque melhoraram a votação pessoal e não pioraram na listagem pela qual concorreram (26,7\% do total). Aproximadamente $75 \%$ desses candidatos (78) melhoraram a performance em votos absolutos em, no mínimo, 20\%, o que se refletiu no posicionamento na lista pela qual concorreram: 72 ascenderam, sendo que 91 poderiam fazê-lo (outros 14 já eram os primeiros colocados), ou seja, 79,1\%. Como resultado, 23 desses 72 tornaram-se líderes ( $25 \%$ dos que poderiam melhorar), e, somados aos 14 que já o eram, totalizam 37 primeiros colocados $(35,2 \%)$. De outro, 96 apresentam performance inversa: eles não se reelegeram ao piorarem a votação pessoal e caírem de colocação na lista ( $24,4 \%$ do total). Acrescenta-se o fato de que $75(78,1 \%)$ diminuíram em, no mínimo, 20\% em comparação aos votos absolutos obtidos em 2002, o que indica claramente 
Reeleição para a Câmara dos Deputados brasileira em 2006 e as incertezas do sistema eleitoral

Alvaro Augusto de Borba Barreto

que a não reeleição ocorreu em função do fracasso individual. ${ }^{19}$ Como reflexo, 73 (76\%) caíram, no mínimo, três posições na lista, em comparação ao pleito em que haviam se elegido.

Há, portanto, 201 situações tidas como "normais", o que significa praticamente a metade dos casos $(51,1 \%)$. Todavia, elas podem não ser tão "lógicas" quanto se possa imaginar, pois deputados com performances idênticas não tiveram o mesmo resultado. É necessário observar esses casos com atenção, visto que eles trazem algum tipo de peculiaridade, a qual precisa ser analisada para uma compreensão mais efetiva da questão.

Dentre os reeleitos, 70 (17,8\% dos casos) reduziram a participação relativa no total de votos válidos e recuaram na lista, dos quais 29 perderam de uma a duas posições. Outros 61 (15,5\%) diminuíram a participação no percentual de votos válidos e não pioraram a colocação na lista. ${ }^{20}$ Como reflexo, dos 49 concorrentes que poderiam melhorar na lista (excluídos os 12 que já eram primeiros colocados), 28 o fizeram $(57,1 \%)$. Há ainda, 23 casos $(5,9 \%)$ em que o parlamentar teve performance positiva e, ainda assim, piorou a ordem na lista. A se destacar que desses, a grande maioria (17) aumentou a performance pessoal em pelo menos $20 \%$, sendo que dois mais do que dobraram o número absoluto de votos. Em sua maioria, o recuo na ordem de classificação foi pequeno, de uma ou duas posições (20 casos), e apenas três caíram no máximo quatro posições.

A mesma situação, mas em sentido inverso, ocorreu com os candidatos que não se reelegeram. Nove $(2,3 \%)$ somaram mais votos, sendo que todos aumentaram o número absoluto de votos em mais de $20 \%$, o que não os impediu de cair de posição na lista (cinco perderam mais de três colocações). Outros 26 (6,6\%) somaram menos votos em termos relativos e não recuaram na lista. Finalmente, três (menos de 1\%) são, aparentemente, os mais "anormais" de todos, pois somaram mais votos, mantiveram ou

19 Ressalve-se que cinco somaram mais votos do que em 2002.

20 Em número absoluto de votos absolutos, 18 melhoraram em 2006. 
avançaram na lista pela qual concorreram e, ainda assim, não conseguiram a reeleição.

Não se pode esquecer que esta é uma disputa em que o desempenho de um está contraposto ao dos demais, por isso todas as situações são perfeitamente razoáveis: um candidato pode piorar a sua performance e ascender na lista, desde que os outros componentes da lista tenham desempenho ainda pior; na mesma medida, ele pode melhorar e recuar, se os demais forem mais eficientes. A última situação mostra o quanto se intensificou a disputa interna, bem como que a performance do candidato foi melhor em comparação tão-somente aquela que ele havia apresentado na eleição anterior, todavia não em relação à competitividade existente na disputa mais recente.

Conquistar o mandato nessas condições também faz parte da racionalidade do sistema eleitoral, visto que, além da disputa interna às listas, torna-se necessário considerar o desempenho do partido ou da aliança pela qual a eleição é disputada. A coligação cria um "partido virtual" ao associar a votação de todos os candidatos e de todas as legendas que estão unidas, e distribui as eventuais cadeiras conquistadas, segundo a ordem de classificação de cada candidato, independentemente da legenda a que pertence e do aporte de votos que esta agregou. Logo, é bastante provável que a colocação em uma lista não seja perfeitamente correspondente à classificação obtida na outra, apesar de servir como indicador do nível de competitividade enfrentada pelo concorrente a cada pleito.

\section{O desempenho da lista pela qual o candidato concorreu}

Tendo em vista a questão, decidiu-se incluir mais um elemento à análise dos casos particulares: o desempenho da lista pela qual o candidato concorreu em 2006, comparado ao da lista a que havia se vinculado em 2002, conforme a Tabela 7. 


\begin{tabular}{|c|c|c|c|}
\hline $\begin{array}{l}\text { Reeleição para a Câr } \\
\text { sistema eleitoral } \\
\text { Alvaro Augusto de Bo }\end{array}$ & reto & 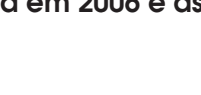 & rezas do \\
\hline \multicolumn{4}{|c|}{$\begin{array}{l}\text { Tabela } 7 \text { - Comparação entre resultado dos candidatos à reeleição } \\
\text { na Câmara dos Deputados em } 2006 \text { e performance da lista pela } \\
\text { qual concorreu, em relação a } 2002\end{array}$} \\
\hline Situação & Reeleito & Não reeleito & Total \\
\hline Positiva & $139(35,4 \%)$ & $56(14,3 \%)$ & $195(49,6 \%)$ \\
\hline Negativa & $120(30,5 \%)$ & $78(19,8 \%)$ & $198(50,4 \%)$ \\
\hline Total & $259(65,9 \%)$ & $134(34,1 \%)$ & 393 (100\%) \\
\hline
\end{tabular}

Fonte: TSE, Resultados - Eleições 2002 e 2006.

Os resultados não diferem radicalmente dos anteriores, pois $55,2 \%$ dos casos correspondem aos cenários esperados: a lista não piorou e o candidato se reelegeu $(35,4 \%)$ ou a lista piorou e o candidato perdeu o mandato $(19,8 \%)$. No entanto, as situações menos esperadas formam quase metade das ocorrências e o percentual de reeleição, quando a lista piora também é alto $(46,3 \%, 120$ em 259 ocorrências), assim como o de insucesso, quando o desempenho do partido ou coligação não piora (41,8\%, 56 em 134 casos).

Pode-se argumentar que tal correlação não é a mais correta, visto que se está supondo a possibilidade de reeleição a partir do desempenho do conjunto de concorrentes da lista, sem levar em consideração a performance individual do candidato. Se tal desempenho for muito ruim, de pouco vai adiantar saber que a lista manteve ou ampliou o número de cadeiras. ${ }^{21}$ Por isso, a seguir o resultado da tentativa de reeleição está relacionado à performance da lista, assim como com a do candidato intralista. Os dados relativos a se ele aumentou ou não o número de votos são apresentados com menos destaque, pelas razões apontadas anteriormente.

As informações trazidas pela Tabela 8 ajudam a explicar com

21 No entanto, é possível (embora improvável) que o desempenho dos outros garanta a vaga do candidato, ainda que ele apresente desempenho risível. O exemplo do Prona, em São Paulo, no pleito de 2002 (ou melhor, do candidato Enéas) comprova o fato: quatro concorrentes foram eleitos com menos de 700 votos (equivalentes a, no máximo, cerca de $0,003 \%$ dos votos válidos do maior colégio eleitoral do país). 
mais propriedade as ocorrências registradas no pleito de 2006, bem como a formular "axiomas" para entender a operacionalidade do sistema eleitoral brasileiro.

Tabela 8 - Resultado dos candidatos à reeleição na Câmara dos Deputados em 2006, performance da lista e posicionamento deles intralista em relação a 2002

\begin{tabular}{|c|c|c|c|c|c|}
\hline \multirow{2}{*}{$\begin{array}{l}\text { Posição } \\
\text { na lista }\end{array}$} & \multicolumn{2}{|c|}{ Reeleito } & \multicolumn{2}{|c|}{ Não reeleito } & \multirow{2}{*}{ Total } \\
\hline & Lista + & Lista - & Lista + & Lista - & \\
\hline Positiva & $73(18,6 \%)$ & $93(23,7 \%)$ & - & $29(7,4 \%)$ & $\begin{array}{c}195 \\
(49,6 \%)\end{array}$ \\
\hline Negativa & $66(16,8 \%)$ & $27(6,8 \%)$ & $56(14,2 \%)$ & $49(12,5 \%)$ & $\begin{array}{c}198 \\
(50,4 \%)\end{array}$ \\
\hline Sub-total & $139(35,4 \%)$ & $120(30,5 \%)$ & $56(14,2 \%)$ & $78(19,9 \%)$ & \\
\hline Total & \multicolumn{2}{|c|}{$259(65,9 \%)$} & \multicolumn{2}{|c|}{$134(34,1 \%)$} & $393(100 \%)$ \\
\hline
\end{tabular}

Fonte: TSE, Resultados - Eleições 2002 e 2006.

Só há um modo de o candidato ter certeza de que estará eleito: quando a lista pela qual estiver concorrendo apresentar desempenho ao menos igual ao do pleito anterior e ele não piorar de colocação nessa lista. Nesse caso, tanto faz que tenha somado mais votos ou não, embora a performance superior aumente a probabilidade de, no mínimo, manter a posição. ${ }^{22}$ Houve 73 dessas ocorrências $(18,6 \%)$, sendo que em 54 casos o concorrente somou mais votos e em 19 teve desempenho negativo. Por isso, não houve nenhum caso da situação inversa, qual seja, de candidato que não se reelegeu apesar de não ter piorado na lista, quando esta repetiu ou melhorou a performance em relação àquela pela qual ele havia concorrido no pleito anterior. ${ }^{23} \mathrm{~A}$ afirmação de Figueiredo e Limongi (2002, p.309) mostra-se contundente: "em um sistema

22 Nessa situação incluem-se aqueles candidatos que sozinhos somam votação superior ao cociente eleitoral. Todavia, há poucos casos no sistema eleitoral brasileiros: em 2002 e 2006, foram cerca de 30 dentre os 594 deputados e senadores.

23 Obviamente, a certeza em questão é meramente descritiva, visto que, em um pleito concreto, o candidato não tem como garantir antecipadamente que manterá a posição obtida há quatro anos e que a lista, por sua vez, repetirá a performance apresentada por aquela pela qual concorreu, quando conquistou o mandato. 


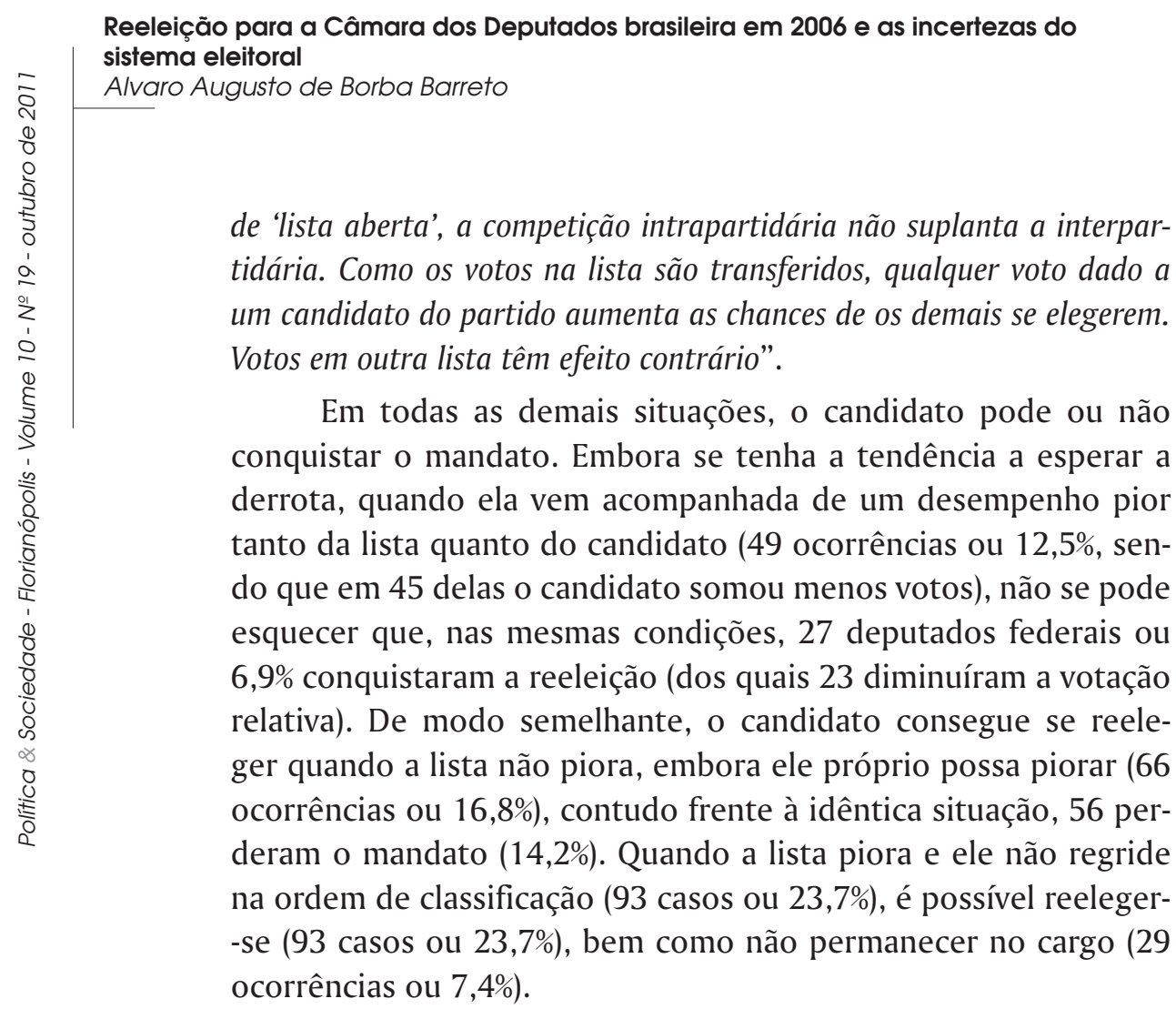

Em meio a tentas possibilidades, torna-se possível elencar tão somente as condicionantes que tornam mais provável a ocorrência de um cenário ou de outro. Antes disso, porém, é preciso lembrar que as informações sobre as listas também trazem alguma dose de imprecisão, pois um partido pode ter participado de uma ampla coligação, em 2002, e tornar-se avulso, em 2006, o que implica recuo da eficiência da lista (seguido ou não por um do candidato), sem que signifique perda de mandato. $\mathrm{O}$ inverso também ocorre: o partido era avulso ou compunha uma coligação que envolvia poucos partidos ou conquistou poucas vagas, em 2002, e passou a uma aliança que obteve muitas cadeiras, em 2006, o que pode significar mais eficiência da lista, acompanhada de recuo do candidato na lista e reeleição. Um bom exemplo é o PMDB, em Minas Gerais: em 2002, conquistou seis cadeiras tendo concorrido isoladamente; e, em 2006, participou de uma coligação ao lado de PT/PRB/PCdoB, que obteve 17 cadeiras. Em termos práticos, o candidato do PMDB mineiro poderia ter sido sexto na lista, em 2002, 
e 17ํㅡ, em 2006, e conseguir o mandato. Outro é o de PTB, PDT e PPS, em São Paulo: em 2002, eles formaram uma aliança que conquistou nove cadeiras; em 2006, cada um concorreu como avulso e o conjunto obteve as mesmas nove cadeiras (PTB quatro, PDT três, PPS duas). A diferença é que os candidatos seriam eleitos, em 2002, chegando até o nono lugar na lista, enquanto que, em 2006, eles deveriam ficar em quarto lugar, na melhor das hipóteses (caso do PTB).

Evidentemente, a probabilidade de o candidato reeleger-se é maior se o partido ou coligação pela qual ele concorreu aumentar o número de cadeiras conquistadas, ainda que, eventualmente, ele perca posições na lista, em comparação ao pleito anterior (tenha ou não melhorado a performance pessoal). Também é possível que o candidato consiga a reeleição ainda que a performance do partido, da coligação e a pessoal sejam piores, e ele recue ou permaneça na mesma ordem de classificação. Nesse caso, esta colocação tem de se manter na faixa correspondente às vagas conquistadas pela lista e, obviamente, a probabilidade de sucesso é maior se o candidato se colocar nos primeiros lugares da lista anterior e/ou recue pouco na lista atual.

Na mesma medida o candidato pode não se reeleger, quando avança ou não perde posições na lista, isso porque a lista pela qual concorreu apresentou um aproveitado pior em comparação a que havia adotado quatro anos antes. Quando o próprio candidato reduziu a participação no total de votos válidos, sem ter perdido posição, já há um indício do desempenho pior dos demais componentes da lista, o que aumenta a probabilidade de uma performance coletiva menos expressiva. Nesse caso, o posicionamento pessoal (igual ou melhor) não se mostrou suficiente para compensar a perda apresentada pela lista.

Em tais situações, a magnitude do distrito também afeta esta probabilidade, haja vista que, com menos cadeiras em disputa, a margem de recuo é menor. Em 2006, a coligação que se mostrou mais eficiente em distritos de magnitude oito conquistou seis cadeiras, ou seja, garantiu vaga para o sexto mais votado (PP/PT/ 


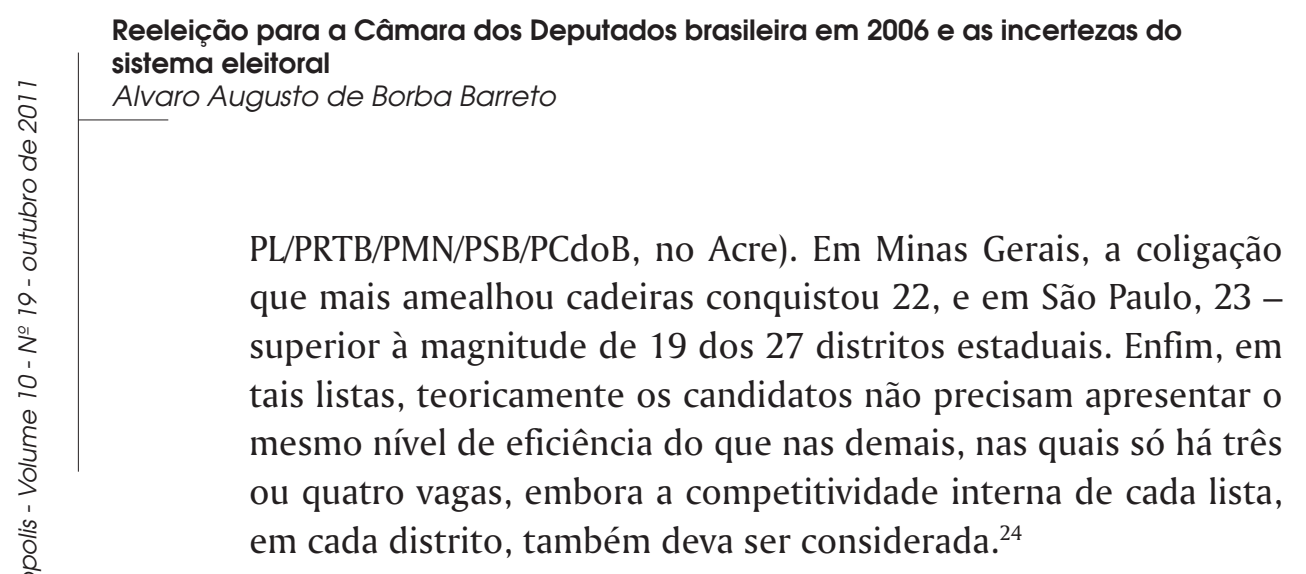

\section{Conclusão}

A principal observação retirada das análises é que uma diversidade de fatores atua concomitantemente no processo de tentativa de reeleição, o que confirma plenamente as afirmações constantes na bibliografia: o sistema eleitoral brasileiro possui altas doses de imprevisibilidade e nenhum dos elementos envolvidos na disputa consegue ter a certeza sobre o nível de desempenho necessário para atingir os seus objetivos (no caso específico, a reeleição). Por consequiência, o elenco de combinações e de possibilidades é bastante vasto, o que dificulta definir quais elementos são imprescindíveis para o sucesso. O que se pode fazer é selecionar alguns e, a partir deles, formular cenários nos quais a probabilidade da obtenção de reeleição é maior ou menor.

Em tese, estará reeleito quem conseguir mais votos e uma melhor posição na listagem, quando esta conquista mais cadeiras, ou seja, quem apresenta índices positivos nos três indicadores de sucesso considerados, tenha ou não aumentado a performance pessoal em votos.

A situação é muito mais imprevisível para aqueles que não possuem indicadores de mesma intensidade. Melhorar a performance individual é um indício de que o candidato estará em melhor posição na listagem, mas a relação não é automática nem necessária, visto que esta depende da concorrência interna, sendo

24 Tal questão ainda precisa ser testada para confirmar a expectativa. 
que a maioria dos candidatos participa de listas diferentes a cada pleito. Logo, foram encontradas situações em que a performance superior do candidato significou tanto não piorar como piorar de posição, também tendo ocorrido o inverso: performance inferior e piora, manutenção ou ascensão na lista. Além disso, uma performance superior e o avanço ou a manutenção da posição em uma lista menos competitiva podem se mostrar insuficiente para conquistar a reeleição, enquanto uma performance inferior e o recuo em uma lista mais competitiva podem garantir um novo mandato.

Na mesma medida, estar em melhor posição na lista torna mais provável a reeleição, mas é preciso considerar se a performance do partido/coligação pela qual concorreu for pior do que a apresentada no pleito em que ele conquistou o mandato. Caso isso ocorra, a posição intralista necessariamente tem de estar na margem de cadeiras obtidas pela lista, caso contrário, o candidato perderá o mandato.

Ao inverso, ele pode conseguir a reeleição, embora diminua o desempenho pessoal e/ou o posicionamento na listagem, e ainda que o partido ou coligação diminua a quantidade de vagas conquistadas. A "mágica" está no fato de que, nesse caso, o recuo do candidato tem de permanecer na faixa de classificação das vagas obtidas pela legenda.

Enfim, do ponto de vista do elenco de possibilidades criadas pelo modo como está articulado o sistema eleitoral brasileiro, nenhuma das situações surpreende e é inusitada, embora possam assim parecer a um primeiro olhar. A questão é que, apesar de "racionais" e sistêmicas, tais combinações efetivamente ampliam a imprevisibilidade do processo eleitoral e impedem que concorrentes (candidatos, partidos) e os cidadãos como um todo possam controlar tais elementos, planejar a sua ação político-eleitoral ou simplesmente entender como esta lógica opera. E quando o sistema é complexo e dotado de certa opacidade, na qual situações 
Reeleição para a Câmara dos Deputados brasileira em 2006 e as incertezas do sistema eleitoral

Alvaro Augusto de Borba Barreto

menos usuais mostram-se possíveis e reais, a tendência é que as próprias regras que o disciplinam sejam tidas como inoperantes, desnecessárias ou simplesmente vazias de significado.

Recebido em: 12.07.2010

Aprovado em: 23.08.2011

\section{Referências}

AMES, B. Os Entraves da democracia no Brasil. Rio de Janeiro: Fundação Getúlio Vargas, 2003.

Electoral rules, constituency pressures, and pork barrel: bases of voting in the brazilian congress. The Journal of politics, v.57 (2), may, 1995.

ARAÚJO, S. C. A Renovação parlamentar no Brasil. Rio de Janeiro. Dissertação (Mestrado em Ciência Política). Iuperj, 2002.

CÂMARA DOS DEPUTADOS. 2008. Deputados - 52 ${ }^{\mathrm{a}}$ Legislatura (2003 a 2007). Disponível em: <http://www2.camara.gov.br/ deputados > Acesso em 26 abr. 2008.

CAREY, J.M. ; SHUGART, M.S. Incentives to Cultivate a Personal Vote: a rank ordering of electoral formulas. Electoral Studies, v. 14 (4), 1995.

CARNEIRO, L.P. ; SCHMITT, R.A. Eleições casadas, resultados nem sempre solteiros: campanhas proporcionais e imagem partidária no Horário Gratuito de Propaganda Eleitoral. Opinião Pública. Campinas, 3 (1), 2001.

CARVALHO, N. R. de. E no Início eram as bases: geografia política do voto e comportamento legislativo no Brasil. Rio de Janeiro: Revan, 2003.

DIAP / CONGRESSO EM FOCO. O Que Esperar do novo Congresso: perfil e agenda da legislatura 2007/2001. Brasília : DIAP / Congresso em Foco, 2007

FIGUEIREDO, A. ; LIMONGI, F. Executivo e Legislativo na nova ordem constitucional. Rio de Janeiro: Fundação Getúlio Vargas, 1999. 
. Congresso Nacional: organização, processo legislativo e produção legal. Cadernos de Pesquisa Cebrap. São Paulo: Entrelinhas, 5, out., 1996.

. Incentivos eleitorais, partidos e política orçamentária. Dados. Rio de Janeiro, 45 (2), 2002.

FLEISCHER, D. Renovação política - Brasil 1978: eleições parlamentares sob a égide do Pacote de Abril. Revista de Ciência Política. Rio de Janeiro: Fundação Getúlio Vargas, v.23 (2), 1980.

- O Pluripartidarismo no Brasil: dimensões sócioeconômicas e regionais do recrutamento legislativo (1946-1967). Revista de Ciência Política. Rio de Janeiro: Fundação Getúlio Vargas, v.24 (1), 1981.

KLEIN, C. O Desafio da reforma política. Rio de Janeiro: Mauad, 2007.

LEONI, E.; PEREIRA, C. ; RENNÓ, L. Estratégias para sobreviver politicamente: escolhas de carreiras na Câmara de Deputados do Brasil. Opinião Pública. Campinas (9), maio, 2003.

LIMA JÚNIOR, O.B. (Org.). Sistema eleitoral brasileiro - teoria e prática. Rio de Janeiro: Rio Fundo/luperj, 1991.

Democracia e instituições políticas no Brasil dos anos 80. São Paulo: Loyola, 1993.

. (Org.). O Sistema partidário brasileiro. Rio de Janeiro: Fundação Getúlio Vargas, 1997.

. Partidos, eleições e poder legislativo In: MICELI, S. (Org.).

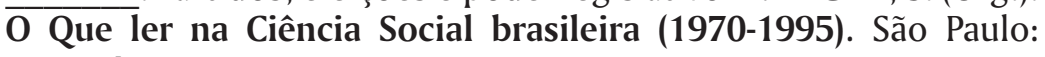
Sumaré/Anpocs, v.3, 1999.

MARENCO DOS SANTOS, A. Não se fazem mais oligarquias como antigamente: recrutamento parlamentar, experiência política e vínculos partidários entre deputados brasileiros (1946-1998). Porto Alegre. Tese (Doutorado em Ciência Política). UFRGS, 2000.

. Regras Eleitorais Importam? Modelos de Listas Eleitorais e seus Efeitos sobre a Competição Partidária e o Desempenho Institucional. Dados. Rio de Janeiro, 49 (4), 2006. 
Reeleição para a Câmara dos Deputados brasileira em 2006 e as incertezas do sistema eleitoral

Alvaro Augusto de Borba Barreto

. Nas Fronteiras do campo político. Raposas e outsiders no congresso nacional. Revista Brasileira de Ciências Sociais. São Paulo, (33), 1997.

MAINWARING, S. Sistemas partidários em novas democracias: o caso do Brasil. Rio de Janeiro/Porto Alegre: Fundação Getúlio Vargas/Mercado Livre, 2001.

Políticos, partidos e sistemas eleitorais: o Brasil numa perspectiva comparativa. Novos Estudos Cebrap. São Paulo (29), 1991.

MELO, C.R. Retirando as cadeiras do lugar - migração partidária na Câmara dos Deputados (1985-2002). Belo Horizonte: UFMG, 2004.

MORGENSTERN, S. Explaining legislative politics in Latin America In: MORGENSTERN, S. / NACIF, B. (Ed.). Legislative politics in Latin America. Cambridge: Cambridge University Press, 2002.

NICOLAU, J. Multipartidarismo e democracia: um estudo sobre o sistema partidário brasileiro (1985-94). Rio de Janeiro: Fundação Getulio Vargas, 1996.

Como Controlar o Representante?: Considerações sobre as Eleições para a Câmara dos Deputados no Brasil. Dados. Rio de Janeiro, 45 (2), 2002.

. O sistema eleitoral de lista aberta no Brasil. Dados. Rio de Janeiro, 49 (4), 2006.

NOVAES, C.A.M. Dinâmica institucional da representação: individualismo e partidos na Câmara dos Deputados. Novos Estudos Cebrap. São Paulo, (38), 1994.

PEREIRA, C. ; RENNÓ, L. O que é que o reeleito tem? Dinâmicas político-institucionais locais e nacionais nas eleições de 1998 para a Câmara dos Deputados. Dados. Rio de Janeiro, 44 (2), 2001.

O que é que o reeleito tem? O retorno: o esboço de uma teoria da reeleição no Brasil. Revista de Economia Política. São Paulo, 27 (4), out./dez., 2007.

RODRIGUES, L. M. Mudanças na classe política brasileira. São Paulo: Publifolha, 2006. 
SAMUELS, D. Ambition, Federalism and Legislative Politics in Brazil. New York: Cambridge University Press, 2003.

- Ambition and competition: explaining legislative

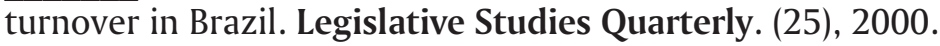

. Determinantes do voto partidário em sistemas eleitorais centrados no candidato: evidências sobre o Brasil. Dados. RJ, 40 (3), 1997.

SANTOS, F. Deputados federais e instituições legislativas no Brasil: 1946-99 In: BOSCHI, R. ; DINIZ, E. ; SANTOS, F. Elites políticas e econômicas no Brasil contemporâneo. São Paulo: Fundação Konrad Adenauer, 2000.

SANTOS, F. Recruitment and Retention of Legislators in Brazil In: LOWENBERG, G. ; SQUIRE, P. ; KIEWIET, D. R. (orgs.). Legislatures - Comparative Perspectives on Representative Assemblies. Ann Arbor, The University of Michigan Press, 2002.

SANTOS, W. G. dos. Eleição, representação, política substantiva. Dados. Rio de Janeiro (8), 1971.

. Da Poliarquia à oligarquia? Eleições e demanda por renovação parlamentar. Sociedade e Estado, 12 (1), jan.-jun., 1997.

Crise e castigo: partidos e generais na política brasileira. São Paulo: Vértice, 1987.

. O Cálculo do conflito. Belo Horizonte: UFMG, 2003.

. (Org.). Votos e partidos. Almanaque de dados eleitorais: Brasil e outros países. Rio de Janeiro: Fundação Getúlio Vargas, 2002.

(Coord.). Almanaque de dados eleitorais: Brasil e outros países. Disponível em: < http://www.ucam.edu.br/leex/index.asp>. Acesso em 22 maio 2008.

SCHMITT, R. A. Migração partidária e reeleição na Câmara dos Deputados. Novos Estudos Cebrap, São Paulo (54), 1999.

SOARES, G. A. D. ; D'ARAÚJO, M. C. A imprensa, os mitos, e os votos nas eleições de 1990. Revista Brasileira de Estudos Políticos. Belo Horizonte (76), 1993. 


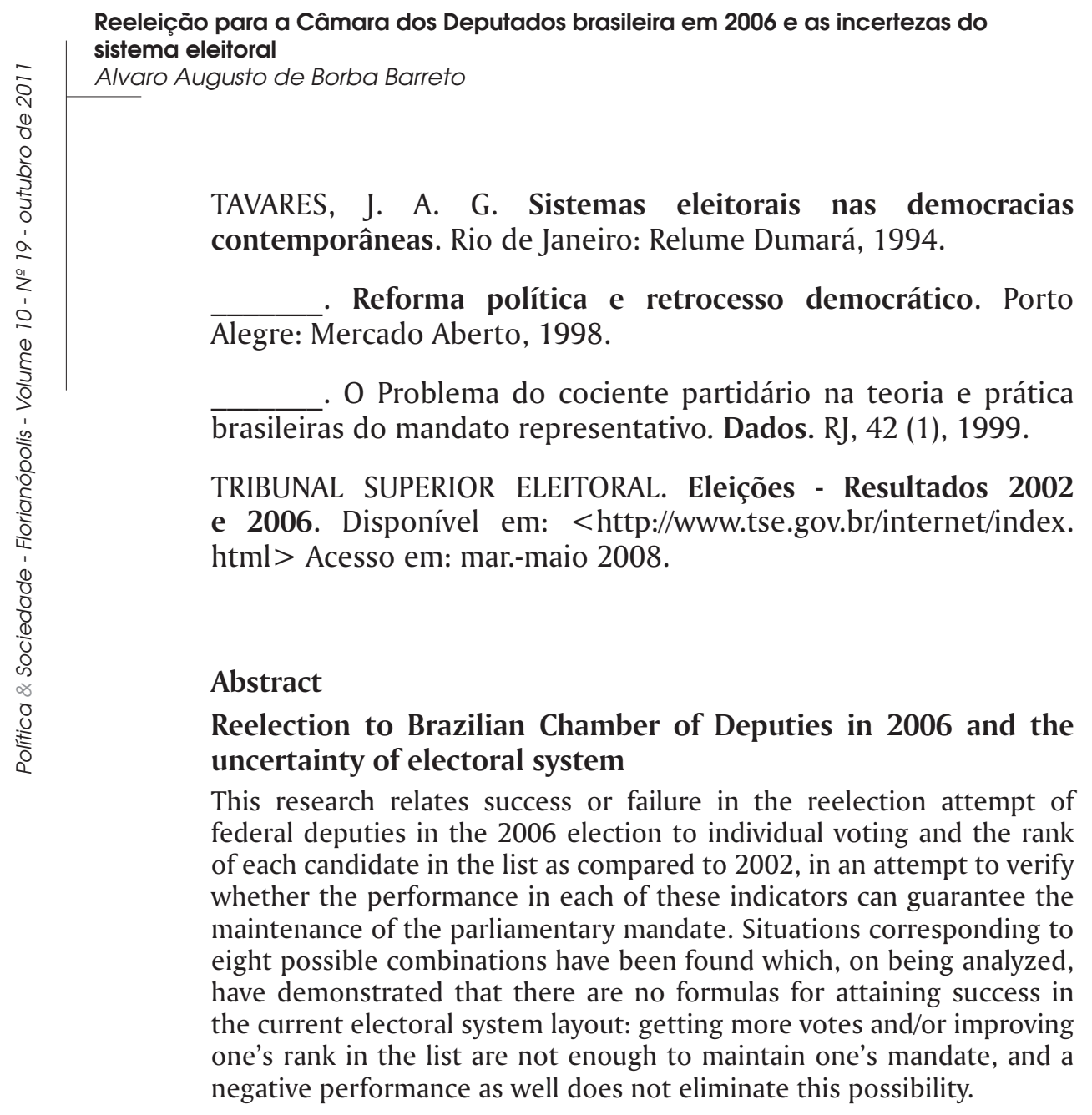

Keywords: reelection, parliamentary renovation, political system, Chamber of Deputies. 